\title{
LXXSA - A new association in old clothing
}

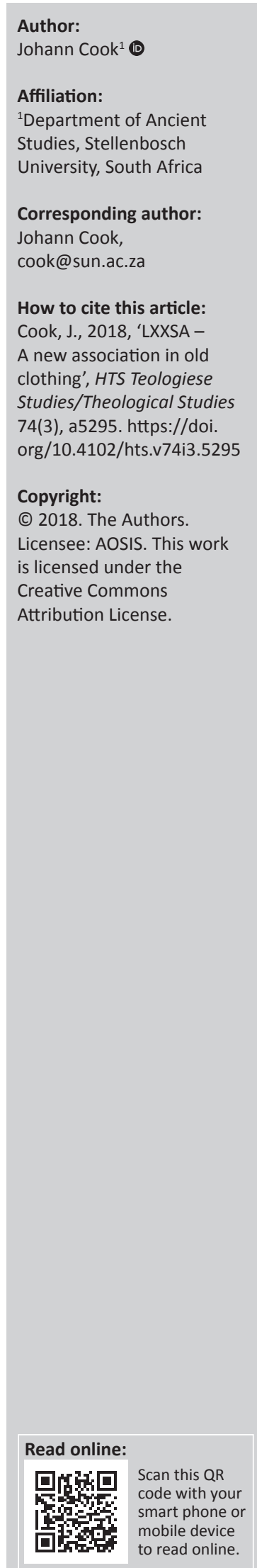

Formal and informal study of the Septuagint has been going on for a long time in South Africa (SA). Prof. Frank Charles Fensham, former chairperson of the Department of Ancient Studies (then known as Semitic Languages), was one of the first scholars in SA to work on the Septuagint. His topic was the term $\alpha \beta \beta \sigma \sigma o \zeta$ in Genesis 1 verse 2 (Cook 2017:5). One of the reasons why the LXX was addressed only informally in SA until recently is the limited influence of the Catholic Church in this country. As is well known, the Protestant canon excludes the deutero-canonical books, which led to an undervaluation of this corpus. Yet studies of the deutero-canonical books found a niche in Septuagintal studies in SA. This is partly the result of collaboration between South African - more specifically the North-West University - and Austrian institutions (Reiterer 2016:27). Hence, the subtitle of the proceedings of a conference held in Potchefstroom, 28-30 August 2015, was Studies on the Septuagint, Apocryphal and Cognate Literature.

Before 2007 the Septuagint was researched in a relatively unorganised way in SA. Nevertheless, conferences were organised and the results of LXX research were published and tested. Conferences such as the three recent ones at the University of Stellenbosch were the result of bilateral research projects. The first one in collaboration with colleagues from the KU Leuven was entitled Textual Studies in early Judaism - The Septuagint and the Dead Sea Scrolls (2006-2007); the proceedings were published in 2008 under the editorship of M. Vervenne, F. García Martinez, H. Ausloos, B. Lemmelijn and J. Cook. The results of the second informal research project were published in 2009 as Septuagint and Reception (J. Cook [ed.], Vetus Testamentum Supplementum, vol. 127, Brill, Leiden). A third conference was presented in conjunction with Prof. H.-J. Stipp from the Ludwig Maximilian University of Munich entitled Text-Critical and Hermeneutical Studies in the Septuagint (2009-2011). The results were published in 2012. There are also other examples of these rather informal ad hoc endeavours.

In 2007 an association was formed at the North-West University (Jordaan \& Allen 2016) with the name Association for the Study of the Septuagint in South Africa (LXXSA). Since then Septuagint research has been conducted more systematically. An executive was formed, with Johann Cook as the chairperson, Pierre Jordaan as the secretary and Gert Steyn as an additional member. To be sure, this executive still functioned relatively informally. It should be stated that there are plans in place to approach the organisational structure more formally.

All along one priority was kept in place: The publication of papers. We do not just talk, but publish as well. Various options were pursued. Initially, preference was given to the possibility of publishing in JSem. And Acta Patristica et Byzantina was once approached. Ultimately, another possibility was considered, namely, HTS Theological Studies. What finally led to the decision in favour of this option is, firstly, that it is an Internation Scientific Indexing (ISI)-evaluated periodical and, secondly, that the open access structure allowed an unlimited amount of publishing space.

The current volume is evidence of the vibrant character of the research activity of LXXSA. The Septuagint proper is the major focus of attention. The deutero-canonical literature is given its fair share. Theoretical issues are reflected upon and finally a Latin text of Jerome is discussed.

In the opening article, entitled 'Recent Developments in Septuagint Research', Johann Cook presents an overview of novel developments in Septuagint research. He argues that the time and opportunity has finally arrived for implementing the next phase of Septuagint research hermeneutical research is at hand. ${ }^{1}$ This phase naturally requires application of the correct methodology. This applies to an acceptable textual theory as well as to the reconstruction of the textual history of the LXX. Novel research (monographs) and new research projects in conjunction with existing projects (exegetical commentaries, a theology of the Septuagint) are discussed.

1.See the presidential address of Johann Cook at IOSOT 2016 held at the University of Stellenbosch, $04-09$ September, entitled 'Interpreting the Septuagint', published in VTS, vol. 177, 2017, pp. 1-22. 
Three more articles are devoted to the Septuagint. Douglas Mangum addresses "The Biblical Hebrew idiom "lift the face" in the Septuagint of Job'. In his own words:

The aim of the study was to determine how the translators of the Septuagint typically handled the implicit meaning of figurative language and to examine whether the translator of the Septuagint of Job followed similar strategies since Job is known to be one of the books where the Septuagint is more literary than literal.

It is immediately evident that figures of speech pose a unique problem for translators simply because the intention of figurative expressions is not apparent from the sum of their parts. These textual phenomena change over time and are contextually bound. Hence, geographical area and dialect must be accounted for when evaluating translations. The author opted for an exhaustive methodological orientation. He correctly chose Translation Studies and more specifically research on translation norms. He also combined this with Cognitive Linguistics. The works by Toury (1995) on Descriptive Translation Studies (DTS) (also called polysystems theory) and on narrative framing in translation by Baker (2006) are significant secondary sources. It must be kept in mind that analysis and interpretation of translated literature requires a methodology different from that for compositional literature.

As to be expected, theoretical issues are dealt with by the couple, Cynthia Miller-Naudé and Jacobus Naudé, in a contribution entitled 'Editorial theory and the range of translations for "Cedars of Lebanon" in the Septuagint'. The authors used a complex theoretical approach in the context of editorial theory (the new science of exploring texts in their manuscript context). They further aimed to determine which cultural values of the translators have influenced their choices and how these values shaped the metaphorical and symbolic meaning of plants as determined by biblical plant hermeneutics, which places the taxonomy of flora on a strong ethnological and ethnobotanical basis.

New ground is broken in this volume on a methodological level. New Philology as a philological perspective within the larger field of Editorial Theory provides a model broadly conceived for understanding texts, text production and transmission, as well as for exploring texts in their manuscript contexts. Each individual manuscript (or inscription or tablet, etc.) is viewed as a meaningful, historical artefact and variants found in these manuscripts are viewed as potentially interesting in their own right. The aim of New Philology is to study texts as (1) integral parts of historically existing manuscripts and (2) to interpret the texts in light of the context of the manuscript and its historical usage.

Koos Kritzinger and Susan Haskins dealt with a Latin text in their article entitled 'Naming the nameless woman of Jerome's Vita Malchi'. One of the common methods of sidelining women in literature is to leave them nameless. This is the case with the woman in Jerome's Vita Malchi. However, this woman is also vital to the narrative and the development of the title character, Malchus. The aim of this study was to assist in giving this important character an identity by examining the many ways in which she is actually named, firstly, in terms of the roles assigned to her, and then in terms of the associations that can be made between her and other people and characters from Jerome's experience. Using a variety of literary techniques, including close textual as well as intra- and intertextual readings, it was possible to make many such identifications, turning the nameless woman into a named woman.

Next follow a number of deutero-canonical texts. Annette Evans deals with 'Almsgiving as a rhetorical device in 4QTobit?' This article is a sequel to an earlier exploration of the possibility of a shift in the book of Tobit from the Deuteronomistic theological perspective in the beginning to a more nuanced concept of theodicy in the end. The Semitic versions of Tobit found at Qumran are regarded as the earliest witnesses to the story of Tobit, dating from c. 100 BCE to the early part of the 1st century CE. They are unfortunately very fragmentary, but the theme of almsgiving recurs at regular intervals in the narrative. In the beginning, the Deuteronomistic theological perspective is expressed in terms of Tobit's belief that God will reward with prosperity those who give alms to their own kinsmen; however, towards the end the ideology appears to shift from the self-centred 'prosperity cult' orientation to expressing a different motivation for almsgiving. The aim of this article is to test the possibility that the almsgiving references are rhetorical hinges which mark the movement of the narrative into a different ideological viewpoint. The complexity of the manuscript transmission of the story of Tobit in the larger matrix of diachronic cultural and religious trends in the ancient Near East is kept in mind when text-critical problems are encountered.

Pierre J. Jordaan and Chih W. Chang 'Penetration of private places in Theodotion Susanna'. Theodotion Susanna has been studied by various scholars in various ways. Each attempt to give some meaning to this narrative has a different emphasis depending on whether the perspective adopted is either text, context or receiver based. This article presents a mixture of text- and context-based readings. It focuses on the different spaces in Theodotion Susanna, that is, the house, garden, court and, finally, heaven. Each of these spaces is contested, but there can only be one victor.

Helen Efthimiadis-Keith also deals with Tobit in "'Othering" and "self-othering" in the book of Tobit: A Jungian approach". The book of Tobit is replete with various instances of 'othering' that hold the potential for creating alienation and a variety of strong emotions. For example, Tobit 'others' Anna by insisting that she had stolen a goat, whereas she had not. Following a Jungian paradigm, this article reads the various 'otherings' inherent in the interrelationships between the characters as reflections of the main character's relationship with himself. In so doing, it analyses these relationships through Jung's concepts of Eros/Logos and anima/animus to determine the nature of Tobit's 'self-othering' and its effect 
on those around him. It is concluded, among other things, that Tobit's multiple 'self-otherings' and his 'othering' of 'other' characters are because of his suppression of his anima-Eros function that has, in turn, given rise to a dominant (and demonic) animus-Logos.

The contribution by Nicholas P.L. Allen and Pierre J. Jordaan is entitled 'Counting half-shekels - Redeeming souls in 2 Maccabees 12:38-45'. It concerns a highly debated text, namely, 2 Maccabees 12, specifically the problematic verses (38-45), which express a theology that is distinctly nonJewish in import. Indeed, most recent scholars concerned with this passage do not seem to be unanimous with regard to the best interpretation of the events that are described, resulting in a range of different opinions concerning, inter alia, the afterlife, purgatory and/or doctrinal disputes between Pharisees and Sadducees. By means of an interpretivist-constructivist epistemology, the authors advocate that normally traditional Judaism emphasises personal, individual responsibility and accountability, whereas in this text God is portrayed as requiring material, financial payment for wrongdoing and not individual teshuvah. This is in contradistinction to, inter alia, Exodus 30:11-16, and theologically Jewish 'transgression' has clearly metamorphosed into Christian 'sin'. In addition, Judas Maccabeus seems to have retained a half-shekel methodology (employed for Jewish men of military age - soldiers), whilst emphasising the 'atonement for your lives' from Exodus 30:11-16 in a more literal, materialistic, non-Jewish sense and de-emphasising the real need to maintain the Temple as well as the proper, traditional rules of teshuvah.

Eugene Coetzer presented an article on 'The supernatural in the theomachy of 2 Macc. 9:1-29 and its role in the communicative strategy: A syntactical, semantic and pragmatic analysis'. Throughout the prefixed letters and narrative of 2 Maccabees, there is a frequent overemphasis on certain concepts within every section or pericope. This is a logical consequence of such a highly rhetorical work and links to the overarching narrative aim of the text. These emphases lead to the question of their significance specific to this text and its subject matter. This article consequently notes, firstly, that 2 Maccabees deals with sensitive or innovative ideas and moves to drastic ways of conceptualising history in order to substantiate these ideas. It is no surprise, therefore, that in 2 Maccabees 9 one would find an overemphasis on the supernatural drive of world events to prove that the God of the Jews duly and appropriately deals with the enemies of his people. In order to explicate and unfold this process, the main ideas will be highlighted, communicative strategy will be investigated and the possible impact on the reader and/or hearer will be outlined.
The second article by Miller-Naudé and Naudé is entitled 'Lexicography and the translation of "Cedars of Lebanon" in the Septuagint'. Botanical terms in the Septuagint reveal a mass of uncertain and sometimes contradictory data because of the translators' inadequate and inaccurate understanding of the plant. To understand the metaphorical and symbolic meaning of plants, the recent initiative by Biblical Plant Hermeneutics is to place the taxonomy of flora on a strong ethnological and ethnobotanical basis by studying each plant in situ and gathering indigenous knowledge about the plant and its context in the biblical text. This article applies this methodology to the translation of the Hebrew source text

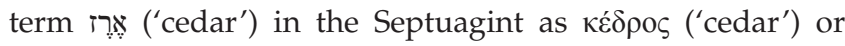
$\kappa \varepsilon ́ \delta \rho ı v o \varsigma$ (the adjectival form of $\kappa \varepsilon ́ \delta \rho \circ \varsigma$ ) and its interpretation in the light of lexicography, which leads to contradictory identifications. A complex theory approach is proposed to provide a solution for the various identification choices in the light of lexicography to communicate the cultural values of the Hebrew source text and its Greek translation.

Finally, Dichk M. Kanonge presents new perspectives in 'Etre and Paraitre: The games of truth in the book of Susanna'. Recent literary methods have opened new possibilities in reading and understanding the logic of narratives. The Greimassian approach offers such a possibility. Though Greimas's approach is by now accepted as part of the canon of narratology, some of its components have not yet received due attention. This is the case with his 'veridictory square', a diagram that applies especially to texts where oppositions such as truth and falsehood, hero and villain, and subject and anti-subject are prominent themes. It is assumed that these kinds of narratives do not concern themselves with objective truth but persuasion about truth, that is, veridiction. Truth telling in those stories corresponds to manipulation, exercising a particular cognitive doing or causing to appear as true. In other words, such a manipulation of truth aims at causing people to believe. Greimas's veridictory square rests on opposing modalities of being (être) and seeming (paraître), the contrast between reality and appearance. This article uses the veridictory square to investigate the games of truth in Susanna and thus offers a new insightful reading of the story.

\section{References}

Baker, M., 2006, Translation and conflict: A narrative account, Routledge, London.

Cook, J., 2017, 'Interpreting the Septuagint', in C. Maier et al. (eds.), Congress Volume 2016 Stellenbosch, pp. 1-22, VTS 176, Brill, Leiden.

Jordaan, P.J. \& Allen, N.P.L., 2016, 'Introduction', in P.J. Jordaan \& N.P.L. Allen (eds.), Construction, coherence and connotations - Studies on the Septuagint, apocryphal and cognate literature, pp. 1-10, De Gruyter, Berlin.

Reiterer, F.V., 2016, 'Three poetic pillars in the Book of Ben Sira: From the divine to human wisdom', in P.J. Jordaan \& N.P.L. Allen (eds.), Construction, coherence and connotations - Studies on the Septuagint, apocryphal and cognate literature, pp. 27-50, De Gruyter, Berlin.

Toury, G., 1995, Descriptive translation studies and beyond, John Benjamins, Amsterdam. 